\title{
PENURUNAN KANDUNGAN PROTEIN PENYEBAB ALERGI PADA PROSES PEMBUATAN SURIMI IKAN NILA (Oreochromis niloticus)
}

\section{Roni Nugraha*, Irama Dramawanti Pamingkas, Rizsa Mustika Pertiwi, Tati Nurhayati}

Departemen Teknologi Hasil Perairan, FPIK IPB University, Jalan Agatis, Kampus IPB Dramaga, Kabupaten Bogor 16680 Jawa Barat Telepon (0251) 8622915, faks (0251) 8622916

Diterima: 28 Agustus 2020/Disetujui: 28 Desember 2020

${ }^{\star}$ Korespondensi: rnugraha@apps.ipb.ac.id

Cara sitasi: Nugraha R, Pamingkas ID, Pertiwi RM, Nurhayati T. Penurunan kandungan protein penyebab alergi pada proses pembuatan surimi ikan nila (Oreochromis niloticus). Jurnal Pengolahan Hasil Perikanan Indonesia. 23(3): 558-565.

\begin{abstract}
Abstrak
Parvalbumin, sebuah protein sarkoplasmik merupakan penyebab utama alergi ikan. Proses pencucian pada pembuatan surimi dapat menghilangkan protein-protein sarkoplasmik dari daging ikan. Oleh karena itu, penelitian ini dilakukan untuk menentukan efek pencucian dan pemanasan serta penambahan enzim terhadap kandungan parvalbumin surimi. Profil protein divisualisasikan menggunakan sodium-deodecyl sulfate polyacrylamide gel electrophoresis (SDS-PAGE) dan intensitasnya diukur. Hasil SDS-PAGE memperlihatkan bahwa proses pencucian menghilangkan protein-protein sarkoplasmik yang diindikasikan dengan menurunnya jumlah dan intensitas pita protein pada surimi. Selain itu, profil protein dari air cucian hampir sama dengan profil protein dari daging ikan segar, menunjukkan bahwa sebagian besar protein dari daging ikan segar terbawa oleh air cucian. Adapun kandungan parvalbumin pada surimi menurun hingga 95\% setelah proses pencucian, dan proses pemanasan maupun penambahan enzim tidak berpengaruh terhadap penurunan parvalbumin. Oleh karena alergenitas ikan berkorelasi dengan kandungan parvalbumin, surimi dapat menjadi alternatif sumber hipoalergenik protein ikan.
\end{abstract}

Kata kunci: air cucian, hipoalergenik, kamaboko, parvalbumin, surimi.

\section{Reduction of Allergenic Proteins during Processing of Tilapia (Oreochromis niloticus) Surimi}

\begin{abstract}
Parvalbumin, a sarcoplasmic protein is the main causative protein of fish allergy. It has been known that during surimi production, many sarcoplasmic proteins are washed away. Thus, this research was aimed to determine the effect of washing processes during surimi production as well as heating and enzyme addition to the parvalbumin content. The protein content of surimi was profiled using sodium-deodecyl sulfate polyacrylamide gel electrophoresis (SDS-PAGE) and their intensity was measured. Washing processes removed sarcoplasmic proteins as indicated by the reduction of the number of bands as well as intensities of protein from surimi samples in the SDS-PAGE. Furthermore, the profile of proteins in the washing solutions was similar to that of raw tilapia extract suggesting majority of proteins from tilapia meat were soluble in the washing solution. The parvalbumin content in the surimi was reduced up to $95 \%$ by washing processes, while heating and addition of enzyme did not greatly affect. As allergenicity of fish products correlate with the parvalbumin content, surimi may be used as an alternative hypoallergenic source of fish protein.
\end{abstract}

Keyword: hypoallergenic, kamaboko, parvalbumin, surimi, wash water 


\section{PENDAHULUAN}

Ikan merupakan sumber makanan yang mengandung protein tinggi yang memiliki asam amino esensial yang lengkap. Daging ikan mengandung $18 \%$ protein dan menyumbang sekitar 16\% daging hewani. Kandungan protein pada ikan tidak seperti lemak, yaitu tidak berubah dan tidak tergantung pada musim, makanan, atau siklus reproduksi. Selain itu, karena kandungan kolagen yang rendah, protein ikan sangat mudah untuk dicerna dengan koefisien daya cerna hampir mencapai 100 (Ariño et al. 2013). Protein ikan juga memiliki manfaat untuk kesehatan. Konsumsi protein ikan memperbaiki sensitivitas insulin pada individu yang resisten insulin sehingga mampu mencegah penyakit diabetes tipe2 dan mengurangi komplikasi (Liaset et al. 2019). Kandungan arginina dan glutamina yang tinggi pada protein ikan juga mampu mempertahankan fungsi kardiovaskular ( $\mathrm{He}$ 2009). Akan tetapi, sebagian orang memiliki hipersensitivitas atau alergi terhadap protein ikan.

Alergi ikan merupakan salah satu penyakit akibat adanya kelainan sistem kekebalan tubuh manusia yang menganggap protein ikan adalah zat berbahaya yang masuk ke tubuh. Kelainan sistem kekebalan ini menyebabkan tubuh memproduksi antibodi tipe E (IgE) ketika protein ikan masuk. Antibodi IgE ini kemudian menempel di permukaan sel biang (mastosit). Sel biang ini akan mengeluarkan histamin dan senyawasenyawa kimia lainnya apabila IgE mengikat protein alergenik dari ikan dan menyebabkan gejala alergi (Stephen et al. 2017). Prevalensi alergi ikan diketahui mencapai $0,3 \%$ dari jumlah populasi. Sebagian besar penderita mengalami gejala alergi oleh protein otot parvalbumin, sedangkan sebagian kecil disebabkan oleh protein-protein lain seperti tropomiosin, aldolase, enolase dan kolagen (Ruethers et al. 2018). Parvalbumin, aldolase dan enolase merupakan protein sarkoplasma, sedangkan tropomiosin merupakan protein miofibril yang larut air dan kolagen adalah protein jaringan ikat (Ochiai dan Ozawa 2020).

Alergi ikan merupakan penyakit yang belum bisa disembuhkan. Penderita alergi ikan masih bisa menghindari kemunculan alergi, saran yang diberikan yaitu tidak mengonsumsi daging ikan (Ruethers et al. 2018). Akibat dari saran tersebut penderita alergi ikan tidak akan mendapatkan manfaat yang cukup dari protein ikan. Selain itu, ikan merupakan sumber protein utama pada beberapa golongan masyarakat, sehingga pembatasan mengonsumsi ikan dapat mengurangi asupan protein hewani. Ikan nila merupakan produk perikanan dengan volume produksi yang besar dan memiliki kandungan protein yang tinggi. Namun, beberapa laporan menyebutkan bahwa penderita orang mengalami reaksi alergi seperti gatal-gatal, pembengkakan pada bibir dan lidah setelah mengkonsumsi ikan nila dan antibody IgE, biomarker alergi, bereaksi dengan proteinprotein ikan (Ebo et al. 2010, Liu et al. 2013).

Parvalbumin merupakan protein yang tahan panas dan tidak mudah dicerna oleh enzim protease sehingga proses pengolahan ikan menggunakan panas atau enzim tidak mampu menghilangkan protein penyebab alergi ini (Ruethers et al. 2018). Oleh karena itu, alternatif pengolahan ikan yang mampu menghilangkan kandungan protein-protein penyebab alergi ini perlu untuk diteliti. Surimi merupakan produk olahan ikan yang terbuat dari daging ikan yang telah mengalami pencucian beberapa kali untuk menghilangkan protein larut air, darah (pigmen), dan penyebab bau pada lemak. Proses pencucian tersebut juga diketahui dapat menurunkan kadar kandungan protein alergenik, terutama parvalbumin (Kurata et al. 2017). Oleh karena itu, penelitian ini dilakukan untuk menentukan efek pencucian dan pemanasan serta penambahan enzim terhadap kandungan parvalbumin surimi.

\section{BAHAN DAN METODE Bahan dan Alat}

Bovin serum albumin (BSA), coomassie briliant blue (CBB), etanol, asam fosfat, bisakrilamid 29:1 (30\%) (No Cat. 1610156, BioRad, AS), ammonium persulfate (APS) (No Cat. 1610700, Bio-Rad, AS), Laemmli buffer sample (No Cat. 1610737, Bio-Rad, AS), tris glisin bufer/ TGS buffer running (No Cat. 
1610732, Bio-Rad, AS), tris $\mathrm{HCl}$ 1,5 M, pH 8,5 (No Cat. 1610798, Bio-Rad, AS), tris $\mathrm{HCl} 0,5$ M 5 pH 6,8, (No Cat. 1610799, Bio-Rad, AS), coomassie stain solution (No Cat. 1610436, BioRad, AS) dan marker 10-250 kDa (Bio-Rad, AS). Alat yang digunakan antara lain sentrifuge (Ohaus, Shanghai China) spektrofotometer, homogenizer, dan alat elektroforesis.

\section{Metode Penelitian \\ Pembuatan surimi dan kamaboko}

Surimi dibuat dari daging ikan nila dengan mengacu pada SNI Surimi (2013) dan modifikasi metode (Mahawanich et al. 2010). Daging ikan nila dipisahkan dari kulit, tulang, jeroan dan kepala, kemudian dihaluskan dengan food processor pada kondisi dingin. Daging yang telah dihaluskan dicuci sebanyak dua kali menggunakan air es $\left(4^{\circ} \mathrm{C}\right)$ sebanyak empat kali volume daging. Daging yang telah dicuci kemudian diperas menggunakan kain belacu dan didapatkan surimi ikan nila. Surimi ikan nila yang dihasilkan dibuat menjadi kamaboko dengan menambahkan enzim tripsin (1-4\%) kemudian dipanaskan selama 90 menit pada suhu $40{ }^{\circ} \mathrm{C}$. Sampel yang digunakan yaitu daging ikan nila (DN), surimi pencucian pertama dan kedua (DP1 dan DP2), air pencucian pertama dan kedua (AP1 dan AP2), kamaboko hasil pencucian kedua (KE0), kamaboko penambahan enzim 1-4\% (KE1, KE2, KE3 dan KE4).

\section{Ekstraksi protein larut air}

Protein alergenik pada umumnya adalah protein larut air, sehingga proses ekstraksi perlu dilakukan untuk memisahkan protein tersebut dari matriks daging. Protein larut air dari ikan nila $(\mathrm{DN})$, produk surimi DP1 dan DP2 dan kamaboko (KE0-4) diekstraksi menggunakan larutan Tris- $\mathrm{HCl}(0,1 \mathrm{M}, \mathrm{pH}$ $8,0)$. Masing-masing sampel sebanyak $10 \mathrm{~g}$ dicampurkan dengan $40 \mathrm{~mL}$ bufer Tris- $\mathrm{HCl}$ kemudian dihomogenkan menggunakan homogenizer dengan kecepatan 5.000 rpm selama 2 menit. Sampel kemudian disentrifugasi dengan kecepatan $10.000 \times g$ selama 30 menit pada suhu $4{ }^{\circ} \mathrm{C}$. Supernatan yang telah dipisahkan dari endapan kemudian disaring menggunakan syringe filter 0,45 $\mu \mathrm{m}$. Filter yang didapatkan diukur kadar proteinnya menggunakan metode Bradford dan dilihat profil proteinnya menggunakan sodium dodecyl sulfate polyacrylamide gel electrophoresis (SDS-PAGE). Adapun protein di air cucian surimi diukur kadarnya tanpa melalui proses ekstraksi (AP).

\section{Penentuan kandungan protein dengan metode Bradford}

Kandungan protein larut air dari ikan nila, surimi dan kamaboko dan protein di air cucian surimi diukur dengan metode Bradfrod (Bradford 1976). Protein laut air sebagai sampel sebanyak $40 \mu \mathrm{L}$ dicampurkan dengan 2 mL larutan Bradford kemudian diinkubasi pada suhu ruang selama 10 menit. Intensitas warna yang terbentuk diukur menggunakan spektrofotometer dengan panjang gelombang $595 \mathrm{~nm}$. Larutan bovine serum albumin (BSA) digunakan sebagai standar.

\section{Visualisasi profil protein menggunakan SDS-PAGE}

Profil protein ikan nila (DN), air cucian surimi (AP), surimi (DP) dan kamaboko (KE) divisualisasikan menggunakan SDS-PAGE mengikuti prosedur Nugraha et al. (2018). Protein larut air ditambahkan bufer Laemmli dengan perbandingan 1:1 (v/v) kemudian heating selama 10 menit pada suhu $85^{\circ} \mathrm{C}$. Gel yang digunakan yaitu gel pemisah (separating) $15 \%$ dan gel pengumpul (stacking) 3\%. Bahan pembuatan gel yaitu bis-akrilamid 30\%, bufer tris, SDS 10\%, APS 10\% dan TEMED. Campuran bahan dimasukkan ke dalam plat kaca sebanyak $4 \mathrm{~mL}$ gel pemisah, gel ditunggu sekitar 1 jam hingga mengeras. Gel pengumpul kemudian ditambahkan kedalam plat kaca gel pemisah yang telah mengeras sebanyak $1 \mathrm{~mL}$ dan dipasang sisir sebagai cetakan pembuat sumur kemudian ditunggu hingga padat kembali sekitar 1 jam. Protein larut air dari semua sampel sebanyak $10 \mu \mathrm{g}$ dimasukkan ke dalam sumur SDS-PAGE kemudian dipisahkan dengan memberikan arus listrik pada gel dengan tegangan $170 \mathrm{~V}$ selama 1 jam. Proses running menggunakan bufer running sekitar $400 \mathrm{~mL}$ agar migrasi protein stabil. Protein yang telah dipisahkan divisualisasikan dengan menggunakan Commassie Brilliant Blue (staining) selama 1 jam dan penghilangan 
warna pada gel (destaining) selama 2 jam. Warna yang terserap pada gel mengandung protein kemudian di-fix menggunakan asam asetat $5 \%$ selama semalam. Intensitas warna pada pita protein yang muncul di SDS-PAGE diukur menggunakan perangkat lunak Image Studio ver 5.2 (Li-Cor, Ltd.).

\section{HASIL DAN PEMBAHASAN}

\section{Profil Protein Surimi dan Kamaboko}

Ikan merupakan salah satu penyebab alergi utama yang bersama 7 jenis makanan lainnya, yaitu susu, telur, udang, kacang tanah, kacang pohon, gandum, dan kedelai bertanggung jawab terhadap hampir 90\% insiden alergi di dunia (Flores Kim et al. 2018). Parvalbumin, protein sarkoplasmik yang berperan dalam proses kontraksi otot, merupakan penyebab utama terjadinya alergi ikan (Ruethers et al. 2018). Telah diketahui bahwa dalam proses pembuatan surimi, protein-protein sarkoplasmik dan protein larut air lainnya dapat dihilangkan melalui proses pencucian (Wawasto et al. 2018). Pengukuran protein terlarut menunjukkan bahwa terjadi penurunan kandungan protein terlarut hingga $50 \%$ pada daging ikan nila setelah melalui proses pencucian (Figure 1).

Kandungan protein alergenik pada surimi dan kamaboko ikan nila diobservasi menggunakan SDS-PAGE. Surimi daging ikan nila dibuat melalui dua tahap pencucian. Setelah proses pencucian, surimi dipanaskan untuk mendapatkan kamaboko. Enzim protease dengan konsentrasi 1-4\% ditambahkan dalam proses pembuatan kamaboko. Profil protein pada surimi dan kamaboko dapat dilihat pada Figure 2.

Hasil SDS-PAGE menunjukkan beberapa protein mendominasi kandungan protein terlarut dari daging ikan nila. Protein-protein utama tersebut berada pada pita dengan bobot molekul $10 \mathrm{kDa}, 17 \mathrm{kDa}, 28-30 \mathrm{kDa}, 36-38$ $\mathrm{kDa}, 46-50 \mathrm{kDa}, \sim 100 \mathrm{kD}$. Proses pencucian menghilangkan sebagian besar proteinprotein utama ini yang terlihat dengan

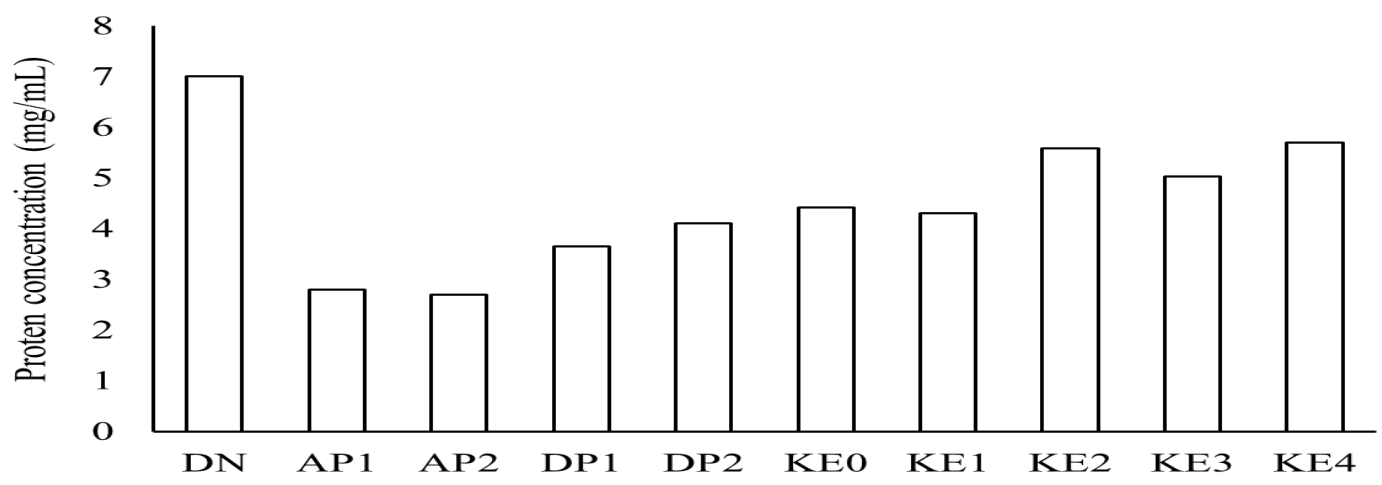

Figure 1 Water soluble protein content of surimi and kamaboko

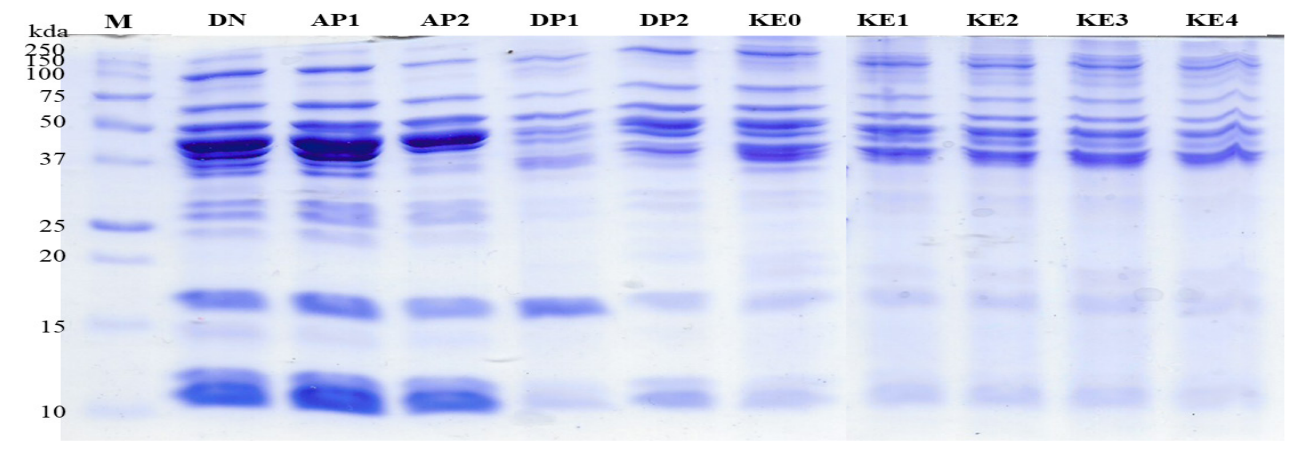

Figure 2 SDS-PAGE profile of the water-soluble proteins extracted from every stage of surimi and kamaboko preparation. (Note: $\mathrm{DN}=$ raw fish extract; $\mathrm{AP1}=$ first washing water; $\mathrm{AP} 2=$ second washing water; DP1: surimi after first washing; DP2; surimi after second washing, KE0 = kamaboko; KE1-4 = kamaboko with addition 1-4\% enzyme) 
adanya kesamaan profil protein pada air pencucian surimi (AP1 dan AP2). Hilangnya sebagian besar protein pada proses pencucian disebabkan $73 \%$ protein yang terdapat pada ekstrak protein daging ikan adalah enzim atau subunit enzim yang memiliki aktivitas katalitik. Kinase merupakan enzim yang paling banyak ditemukan, diikuti oleh alodalase, dehidrogenase, isomerase dan enolase dan sebagian besar enzim-enzim tersebut memiliki bobot molekul 37-50 kDa (Gam et al. 2006). Protein lain yang terlarut dalam proses pencucian adalah parvalbumin $(11 \mathrm{kDa})$, miosin light chain $(17 \mathrm{kDa})$ dan troponin $(28 \mathrm{kDa})$.

Daging surimi banyak mengandung protein berbobot molekul besar $(>40 \mathrm{kDa})$, begitu pula dengan produk kamaboko. Hasil penelitian-penelitian sebelumnya menunjukkan bahwa protein-protein yang terdapat dalam surimi antara lain tropomiosin $(\sim 37 \mathrm{kDa})$, aktin ( 46-50 kDa), a-aktinin $(\sim 100 \mathrm{kDa})$ (Kristinsson dan Liang 2006, Azadian et al. 2012). Hasil SDS-PAGE juga menunjukkan bahwa penambahan enzim dan perlakuan pemanasan pada pembuatan kamaboko tidak mengubah profil protein. Profil protein DP 2 dengan KE0, KE1, KE2, KE3 dan KE 4 memiliki kesamaan.

Kandungan protein pada pita-pita SDSPAGE dapat diukur secara semikuantitatif menggunakan densitometri. Intensitas pitapita protein di SDS-PAGE dipetakan dalam bentuk dendogram yang dapat dilihat di Figure 3. Intensitas pita kemudian divisualisasikan menggunakan warna. Warna merah menunjukkan intensitas tinggi sedangkan putih menandakan intensitas yang rendah. Dendogram memperlihatkan ada perubahan intensitas pada pita-pita di SDS-PAGE. Perubahan profilprotein teramatiketika daging ikan nila diubah menjadi surimi, namun tidak terlihat adanya perubahan yang nyata ketika surimi dibentuk menjadi kamaboko. Pita-pita protein dengan bobot molekul kurang dari $40 \mathrm{kDa}$ memudar, terutama pada pita dengan bobot molekul 10, 17 dan $40 \mathrm{kDa}$. Pita-pita protein yang memudar tersebut disebabkan

\begin{tabular}{|c|c|c|c|c|c|c|c|c|c|c|}
\hline $\begin{array}{c}\text { MW } \\
\text { (kDa) }\end{array}$ & DN & AP1 & AP2 & DP1 & DP2 & KE0 & KE1 & KE2 & KE3 & KE4 \\
\hline 89.7 & & & & & & & & & & \\
\hline 73.7 & & & & & & & & & & \\
\hline 59.0 & & & & & & & & & & \\
\hline 47.8 & & & & & & & & & & \\
\hline 41.8 & & & & & & & & & & \\
\hline 39.7 & & & & & & & & & \\
\hline 36.0 & & & & & & & & & \\
\hline 35.4 & & & & & & & & & & \\
\hline 30.7 & & & & & & & & & & \\
\hline 28.2 & & & & & & & & & \\
\hline 26.8 & & & & & & & & & \\
\hline 24.2 & & & & & & & & & & \\
\hline 16.5 & & & & & & & & & \\
\hline 14.5 & & & & & & & & & & \\
\hline 10.8 & & & & & & & & & \\
\hline
\end{tabular}

Band intensity

Low

Figure 3 Dendogram of protein profiles after SDS-PAGE separation. (Note: DN=raw fish extract; $\mathrm{AP} 1=$ first washing water; $\mathrm{AP} 2=$ second washing water; $\mathrm{DP} 1=$ surimi after first washing; DP2=surimi after second washing, KE0=kamaboko; KE1-4=kamaboko with addition $1-4 \%$ enzyme) 
proses pencucian yang menghilangkan banyak protein, sebagaimana yang terlihat di profil SDS-PAGE AP1 dan AP2.

\section{Kandungan Parvalbumin}

Parvalbumin merupakan penyebab utama alergi ikan. Parvalbumin merupakan protein sarkoplasmik yang memiliki bobot molekul 10-12 $\mathrm{kDa}$ dan mengandung 6 struktur $\alpha$-heliks (A-F) dan segmen pendek $\beta$-sheet (Figure 4). Protein ini memiliki fungsi mengikat kalsium pada proses kontraksi otot. Hasil gambar SDS-PAGE (Figure 2), terlihat adanya 2 pita yang berdekatan dengan bobot molekul sekitar $11 \mathrm{kDa}$ yang merupakan dua molekul parvalbumin. Hal ini sejalan dengan penelitian sebelumnya yang menemukan ikan nila memiliki 2 pita parvalbumin pada SDSPAGE yang keduanya mampu menyebabkan alergi (Ruethers et al. 2018). Hasil penelusuran pada pangkalan data National Center for Biotechnology Information (https:// www.ncbi.nlm.nih.gov/) ditemukan bahwa ikan nila memiliki 4 isomer parvalbumin yang semuanya memiliki bobot molekul sekitar $11 \mathrm{kDa}$. Hasil penyejajaran keempat isomer parvalbumin tersebut memperlihatkan adanya variabilitas pada susunan asam aminonya, kecuali pada 2 daerah tempat pengikatan kalsium yang memiliki susunan asam amino lestari.

Tingkat alerginitas ikan dapat diprediksi dari kandungan parvalbumin dalam dagingnya. Beberapa jenis ikan di antaranya tuna dan todak memiliki kandungan parvalbumin yang rendah sehingga tidak menimbulkan alergi pada penderita alergi ikan (Klueber et al. 2019). Kobayashi et al. (2016) menggunakan teknik SDS-PAGE untuk mengukur kandungan parvalbumin pada beberapa jenis ikan dan mendapatkan bahwa insensitas pita parvalbumin pada SDS-PAGE berkorelasi dengan reaktivitasnya terhadap antibody IgE. Oleh karena itu, pada penelitian ini dilakukan pengukuran kandungan parvalbumin pada produk surimi dan kamaboko. Dari pengukuran intensitas pita pada posisi $10 \mathrm{kDa}$ terlihat adanya penurunan intensitas yang tampak pada daging surimi yang mengalami proses pencucian (Figure 5). Intensitas pita parvalbumin daging ikan nila menurun lebih dari 95\% setelah proses pencucian. Parvalbumin ini terbawa oleh air cucian yang terlihat dari tingginya nilai intensitas parvalbumin di AP1 dan AP2. Penurunan konsentrasi parvalbumin oleh pencucian ini sejalan dengan penelitianpenelitian sebelumnya. Kurata et al. (2017) menggunakan metode enzyme-linked immunosorbent assay (ELISA) mendapatkan konsentrasi parvalbumin pada daging Alaskan pallock menurun $87 \%$ setelah dua kali pencucian dan menurun hingga 99\% setelah lima kali pencucian. Tingkat penurunan parvalbumin ini sama dengan yang didapatkan oleh pada gelatin kulit ikan kod yang
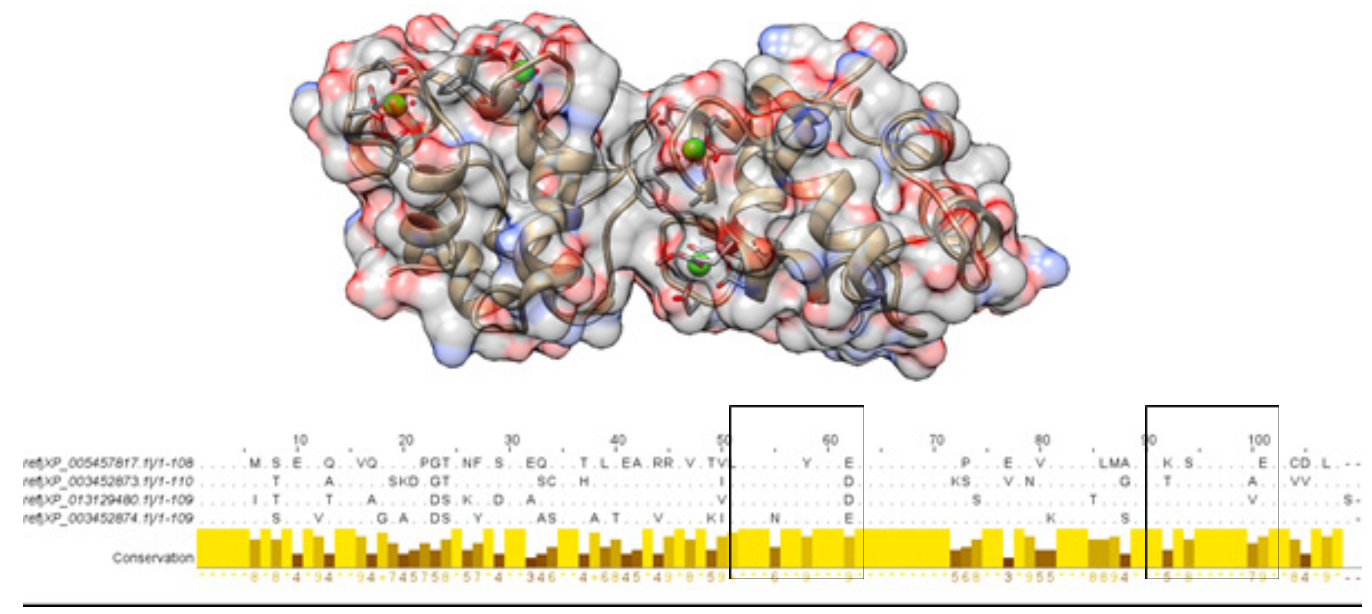

Figure 4 Three dimensional structure modelling of parvalbumin dimer (A) and sequence alignment of four isoforms of parvalbumin from Oreochromus niloticus (B). The black boxes on the alignment indicates the calcium binding sites. 


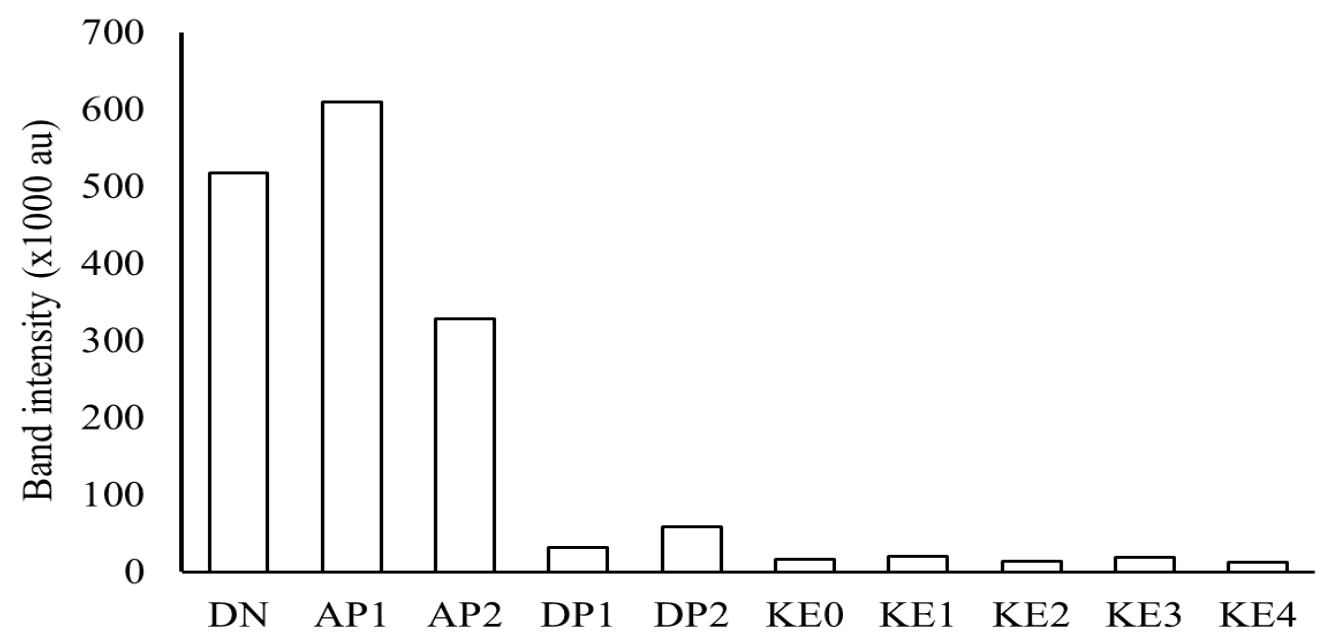

Figure 5 Intensity of parvalbumin band in the SDS-PAGE

mencapai 99\% setelah lima kali pencucian (Koppelman et al. 2012). Proses pemanasan dan penambahan enzim tidak menurunkan kandungan parvalbumin dengan nyata karena parvalbumin merupakan protein yang tahan panas.

\section{KESIMPULAN}

Proses pencucian daging ikan dalam pembuatan surimi dapat menghilangkan protein-protein sarkoplasmik. Berdasarkan pengukuran intensitas pita-pita protein di SDS-PAGE menggunakan densitometri, kandungan parvalbumin pada surimi berkurang hingga 95\% setelah melalui proses pencucian. Oleh karena alergenitas ikan berkorelasi dengan kandungan parvalbumin, surimi dapat menjadi alternatif sumber protein ikan. Akan tetapi pengujian menggunakan antibodi IgE perlu dilakukan.

\section{UCAPAN TERIMA KASIH}

Penelitian ini didanai menggunakan dana Hibah Skim PTUPT tahun 2020 a.n Prof. Dr. Tati Nurhayati, SPi, MSi

\section{DAFTAR PUSTAKA}

Ariño A, Beltrán JA, Herrera A, Roncalés P. 2013. Fish and seafood: Nutritional Value. Encyclopedia of Human Nutrition (Third Edition). B. Caballero. Waltham, Academic. Press: 254-261.

Azadian M, Moosavi-Nasab M, Abedi E. 2012.

Comparison of functional properties and SDS-PAGE patterns between fish protein isolate and surimi produced from silver carp. European Food Research and Technology. 235(1): 83-90.

Bradford MM. 1976. A rapid and sensitive method for the quantitation of microgram quantities of protein utilizing the principle of protein-dye binding. Analytical Biochemistry. 72(1-2): 248-254.

Ebo DG, Kuehn A, Bridts CH, HilgerC, Hentges F, Stevens WJ. 2010. Monosensitivity to pangasius and tilapia caused by allergens other than parvalbumin. Journal of Investigational Allergology and Clinical Immunology. 20(1): 84-88

Flores Kim J, McCleary N, Nwaru BI, Stoddart A, Sheikh A. 2018. Diagnostic accuracy, risk assessment, and cost-effectiveness of component-resolved diagnostics for food allergy: A systematic review. Allergy. 73(8): 1609-1621.

Gam L-H, Leow C-Y, Baie S. 2006. Proteomic analysis of snakehead fish (Channa striata) muscle tissue. Malaysian Journal of Biochemistry and Molecular Biology. 14: 7.

He K. 2009. Fish, long-chain omega-3 polyunsaturated fatty acids and prevention of cardiovascular disease-eat fish or take fish oil supplement?. Progress in Cardiovascular Diseases. 52(2): 95-114.

Klueber J, Schrama D, Rodrigues P, Dickel H, Kuehn A. 2019. Fish allergy management: from component-resolved diagnosis 
to unmet diagnostic needs. Current Treatment Options in Allergy. 6:322-337

Kobayashi Y, Yang T, Yu C-T, Ume C, Kubota H, Shimakura K, Shiomi K, Hamada-Sato N. 2016. Quantification of major allergen parvalbumin in 22 species of fish by SDSPAGE. Food Chemistry. 194: 345-353.

Koppelman SJ, Nordlee JA, Lee PW, Happe RP, Hessing M, Norland R, Manning T, Deschene R, De Jong GAH, Taylor SL. 2012. Parvalbumin in fish skinderived gelatin: is there a risk for fish allergic consumers?. Food Additives \& Contaminants: Part A. 29(9): 1347-1355.

Kristinsson HG, Liang Y. 2006. Effect of pHshift processing and surimi processing on atlantic croaker (Micropogonias undulates) muscle proteins. Journal of Food Science. 71(5): C304-C312.

Kurata K, Itoh M, Matsumiya M, Dobashi A, Itagaki Y, Shiomi K. 2017. Preparation of hypoallergenic kamaboko: removal of parvalbumin and collagen from fish meat by water-bleaching, mechanical grinding and extraction with potassium chloride. Journal of Cookery Science of Japan. 50(4): 141-150.

Liaset B, Øyen J, Jacques H, Kristiansen K, Madsen L. 2019. Seafood intake and the development of obesity, insulin resistance and type 2 diabetes. Nutrition Research Reviews. 32(1): 146-167.

Liu R, Holck AL, Yang E, Liu C, Xue W. 2013. Tropomyosin from tilapia (Oreochromis mossambicus) as an allergen. Clinical and Experimental Allergy. 43(3): 365-377.

Mahawanich T, Lekhavichitr J, Duangmal K. 2010. Original article: Gel properties of red tilapia surimi: effects of setting condition, fish freshness and frozen storage. International Journal of Food
Science and Technology. 45(9): 1777-1786. Nugraha R, Kamath SD, Johnston E, Zenger KR, Rolland JM, O'Hehir RE, Lopata AL. 2018. Rapid and comprehensive discovery of unreported shellfish allergens using large-scale transcriptomic and proteomic resources. Journal of Allergy and Clinical Immunology. 141(4): 1501-1504.e1508.

Ochiai Y, H Ozawa. 2020. Biochemical and physicochemical characteristics of the major muscle proteins from fish and shellfish. Fisheries Science. 86(5): 729-740.

Ruethers T, Raith M, Sharp MF, Koeberl M, Stephen JN, Nugraha R, Le TTK, Quirce S, Nguyen HXM, Kamath SD, Mehr SS, Campbell DE, Bridges CR, Taki AC, Swoboda I, Lopata AL. 2018. Characterization of Ras $\mathrm{k} 1$ a novel major allergen in Indian mackerel and identification of parvalbumin as the major fish allergen in 33 Asia-Pacific fish species. Clinical and Experimental Allergy. 48(4): 452-463.

Ruethers T, Taki AC, Johnston EB, Nugraha R, Le TTK, Kalic T, McLean TR, Kamath SD, Lopata AL. 2018. Seafood allergy: A comprehensive review of fish and shellfish allergens. Molecular Immunology. 100: 28-57.

Stephen JN, Sharp MF, Ruethers T, Taki A, Campbell DE, Lopata AL. 2017. Allergenicity of bony and cartilaginous fish - molecular and immunological properties. Clinical \& Experimental Allergy. 47(3): 300-312.

Wawasto A, Santoso J, Nurilmala M. 2018. Karakteristik surimi basah dan kering dari ikan baronang (Siganus sp.). Jurnal Pengolahan Hasil Perikanan Indonesia. 21(2): 367-376. 